\title{
Overview on Derivatives Trade in China
}

\author{
Tianying Zhou
}

SHU-UTS SILC Business School, Shanghai University

doi: 10.19044/esj.2016.v12n25p153 URL:http://dx.doi.org/10.19044/esj.2016.v12n25p153

\begin{abstract}
Since 1980s, derivatives market has become the significant component of international financial market, and its founding and development contributes to the characteristics of modern financial market. Derivatives, which have gone through the stages of massive import, fast growth and gradual maturity, are one of the fruits of financial creations. It has also led to constructive reform of financial system. As for present market, according to BIS, the notional principle of exchange traded derivatives and options sums to 73.46 trillion US dollars. While the notional value of contract of global OTC derivatives is 691 trillion US dollars, the add-up would be 764.46 trillion US dollars. The OTC derivatives take up $90.39 \%$ global derivatives market. In the meanwhile, according to ISDA statistics, $94 \%$ of global 500 companies trade in OTC derivatives market.
\end{abstract}

Keywords: China, Derivatives, and Transaction

\section{Overview on Financial Derivatives Trade in China}

The financial system inherited by the planned economic system cannot meet the needs of economic development of market because of the persistent and deepening economic reforms in China. Financial reform is imminent, which is also the objective requirement and essential part of economic system reform of China.

\section{Developing of Financial Derivatives Trade in China}

The fundamental function of financial derivatives market had been improved by the rich experience accumulated in the developing of financial derivatives market in China from practicing in early 1990s to rectification and recovery development of new century. Meanwhile, the basic laws, regulation and administrative monitoring framework had been established. The establishment of financial derivatives market experienced the following four stages: the theoretical stage (1987-1990); the establishment and developing of future market (1990-1993); rectification and regulation adjusted period (19941999); recovery development (2000-now). China began to introduce future 
market, currency future, stock index futures, bond futures and warrants trading from 1990. However, most of them were forced to interrupt because of too many problems and disadvantages.

Table 1 the pilot of financial derivatives in China

$$
\begin{gathered}
\text { Type of } \\
\text { financial } \\
\text { derivatives }
\end{gathered}
$$

Bond futures

\section{Currency \\ futures}

Stock index futures
Time

$12 / 1992$

$-5 / 1995$

$6 / 1992-$

$6 / 1996$
Dollar, British pound, Germany mark, Japanese Yen, Hong Kong dollar
The contracts were designed according to the tradable bonds in two-year, threeyear and fiveyear issued from 1992 to 1994
4 contracts based on delivery in March, June, September and December in Shenzhen Composite Index; the other 4 contracts based on Shenzhen A share
Trading

Bond futures opened to investors officially at 25 October 1993, which developed well in 1994.

The trading volume reached 2.8 trillion.

The changing in exchange rate cannot be predicted easily according to the price of currency futures because of the system of double exchange rate. Another reason of less trading and demand is there are many strict requirements in spot trading of foreign exchange The maximal trading volume was just over 200 because of the low awareness of investors. The stock price remained at high level because demand exceeded supply. Not only the stock index

\section{Reason for closing}

A series of vicious violations events like "327 bond" in 1995 leaded to the incapable transactions. The monitoring authorities declared to pause transactions.

Due to the demand exceeds supply in a long term, the central bank and SAFE announced that the "The Proposed Measures of Foreign Exchange Futures Business Management" was invalid at 27

March 1996.

The behaviour of join hands transactions of rich and influential people to decline the stock price index in Futian Securities Department of Shenzhen Pin'an Insurance

Company made monitoring 


\begin{tabular}{|c|c|c|c|c|}
\hline & & & $\begin{array}{c}\text { future were } \\
\text { difficult to } \\
\text { hedge risk, but } \\
\text { also it became a } \\
\text { speculative tool }\end{array}$ & $\begin{array}{l}\text { authorities } \\
\text { announce the } \\
\text { termination of } \\
\text { transaction }\end{array}$ \\
\hline Warrant & $\begin{array}{c}6 / 1992- \\
6 / 1996\end{array}$ & $\begin{array}{l}\text { On behalf of } \\
\text { Feile warrants, } \\
\text { Anbao warrants, } \\
\text { Jinbei warrants } \\
\text { and Shenhua } \\
\text { warrants }\end{array}$ & $\begin{array}{l}\text { Due to the } \\
\text { irrational } \\
\text { designing in } \\
\text { pricing and } \\
\text { mechanisms and } \\
\text { lake of } \\
\text { awareness of } \\
\text { investors, most } \\
\text { of warrant } \\
\text { markets } \\
\text { reflected flat } \\
\text { relatively. }\end{array}$ & $\begin{array}{l}\text { There were no } \\
\text { listing warrants } \\
\text { in stock exchange } \\
\text { after } 30 \text { June } \\
\text { 1993. The spot } \\
\text { trading } \\
\text { dominated in } \\
\text { Chinese } \\
\text { securities } \\
\text { transactions. }\end{array}$ \\
\hline
\end{tabular}

Sourcing: The history of securities in China

Overall, the main reason for the failure of financial derivatives pilot is that the major financial price in Chinese financial market is not entirely decided by the market. The basic survival conditions of financial derivatives are not met. For example, the government still exercises strict control over foreign currency in spite of the completed merging of exchange rate; the real market interest rate has not formed because the government control deposit and loan interest rate and yield rate of treasury bills officially or potentially; the institutional defects like equity division are existing though the stock market turn better.

China has joined the WTO for five years in 2006. The geographical restrictions on foreign banks trading business with RMB in China have been cancelled. The China Financial Futures Exchange has been established in Shanghai by Shanghai Futures Exchange, Zhengzhou Commodity Exchange, Dalian Commodity Exchange and Shanghai Stock Exchange at 8 September 2006, which is also approved by the State Council and China Securities Regulatory. The establishment of China Financial Futures Exchange provide a platform for the trading of financial derivatives in China. There are also important strategic meanings for deepening capital market reform, completing capital market system and developing capital market functions. The main behaviour of OTC derivatives trading in China is inter-bank market, which means the forming of invisible market because of seeing different exchanges among the financial institutions mainly like large commercial banks usually. The clearing platform of central counterparty in China's OTC derivatives called Shanghai Clearing House was established in Shanghai at November 2009. 


\section{Transaction of Financial Derivatives in China}

Compared with the thousands of financial derivatives in the United States, there are few financial derivatives like stock index futures, bond futures and newly listed stock option. The president of China Futures Association, Qing Chang, compares the development of financial derivatives market in China to the same situation in the United States from 1970s to 1980s in the interview of Global Times.

\section{Transaction of Commodity Derivatives}

After China joined the WTO, the internationalization of financial market continuously improves. Hence, investors need financial derivatives for risk management, and improve the management efficiency urgently. According to the report from the China Securities Regulatory Commission (CSRC), trading volume of China's commodity futures has been topped the list in the world for five years. Jiangyang, the vice President of the China Securities Regulatory Commission, pointed out in the report, the trading volume of futures in China improved rapidly in recent years and the daily turnover was nearly one trillion, which occupied around $20 \%$ of the global futures trading volume. Therefore, the futures market made a great contribution to the development of our country's market economy. In 2014, the trading volume of futures market created new high, namely, the cumulative volume of the futures market was 2.505 billion hands, and the cumulative turnover was 291.986659 trillion, with year-on-year growth of 21.54 percent and 9.16 percent respectively, which showed that China already has the world's largest commodity futures market. Under the low inflation, low interest rate and easing monetary policy, the economy in China Presented the periodic characteristics that financial futures was a bear market and commodity futures was a bull market. From the futures market transaction data in 2014, Stock index futures' trading volume soared because stock prices continued to increase in the second half of the year, and stock index soared. Accordingly, most varieties of commodity futures continued to fall, and the bear market pattern was more significant. Under the strong dollar and the international crude oil prices almost halved, commodity futures launched fierce decline. Among them, the price of crude oil presented a step-wise slump, which was near $\$ 50$ per barrel, hitting the lowest point in five years. Besides, Energy, steel, rubber and other more than 20 varieties hit the lowest level in three year. The steel plate suffered the most, namely, the prices of eight varieties of which led by iron ore and rebar reached the lowest point in a decade. Some commodity futures' prices have nearly fallen to the prices of the global financial crisis in 2008, putting an end to the super cycle of bulk commodity. Above all, the sharp increase of both the domestic commodity futures and financial futures' trading volume in 2014 caused that the trading 
volume of futures market in the fourth quarter rose contra-seasonally while the financial futures market was the main force.

The statistics in the first half of 2015 showed that between January and June, the accumulative total turnover of futures market surpassed that in 2014. The stock market was prosperous, the turnover of financial futures in the first half of last year once accounted for over 80 per cent of turnover of total futures market. In the next half year, index futures transaction decreases while commodity futures transaction increases. Since July, the index futures turnover decreased sharply suffered by domestic stock market call-back and a series of strict regulations target on index futures. At the same time, the commodity futures trading volume and turnover showed a significant growth. In details, the volume of non-ferrous metals, precious metals and other industrial plate surged, and in November as well as December, industrial products futures turnover accounted for more than 50 percent. In 2015, the total futures market transaction data grew to a record. The newest statistics from China Futures Association indicated that the cumulative volumes of the domestic futures market was 3.578 billion hands, and the cumulative turnover was 554.23 trillion, with year-on-year growth of 42.78 per cent and 89.81 per cent respectively. In conclusion, by observing two indicators, both volume and turnover were at an all-time high, which exceeded the all of 2014.

After six new types came into market since 2014, the pace of product innovation in domestic futures market remained stable in 2015. In 2015, the amount of new futures products, which were listed for transactions, was five, including Nickel futures and Tin futures belong to Shanghai Futures Exchange, and the 10-year Treasury futures, Shanghai 50 index futures and CSI 500 stock index futures belong to China Financial Futures Exchange. This action further enriched the varieties sequence of non-ferrous metal and financial futures.

\section{Transaction of Exchange Rate Derivatives}

The Bank of China launched the business called RMB future foreign exchange settlement in April 1997. The other three banks out of four also launched the same business in 2004. In addition, China Minsheng Bank, China Merchants Bank and China CITIC Bank also received a license. The turnover of RMB future within the territory of China was still less than 9 billion dollars back to 2003, which only was $1.06 \%$ of trading volume. In fact, the corresponding ratio in worldwide was up to $150 \%$. However, the demand of using derivatives to hedge risk in enterprises and banks was rising with the increasing of flexibility of RMB exchange rate, which also was the inherent requirement of developing in RMB foreign exchange derivatives market. The People's Bank of China and the State Administration of Foreign Exchange issued a series of policies and measures about management of foreign 
exchange transactions from August 2005 to October 2005, which included enlarging the business of future foreign exchange settlement, offering currency swaps of RMB and launching interbank foreign exchange forward transactions. Moreover, the State Administration of Foreign Exchange launched policies and measures about foreign exchange currency swaps of RMB and trading of RMB against foreign exchange options from January to February in 2011. The new policies and measures allowed banks to issue business like foreign currency swaps of RMB, interbank transactions of RMB options and selling RMB options to customers.

The trading volume of foreign exchange derivatives in China develops rapidly in recent years. According to the statistics, the turnover of spot foreign exchange was 4.2 trillion dollars, which was $1.4 \%$ higher than last year. The turnover of foreign exchange derivatives was 4.7 trillion dollars, 34.8\% higher than last year. The turnover of foreign exchange derivatives exceeded the spot foreign exchange, which was accounted for 53\% and increasing $7.1 \%$ compared with last year.

\section{Transaction of Interest Rate Derivatives}

The main transactions of interest rate derivatives in China's financial derivatives market include bond forwards and interest rate swaps of RMB. The interbank market introduced the buying out type repurchase back to 2004, which had the feature of going short. The transactions of bond forward were launched in May 2005, which referred to the beginning of first Chinese OTC derivatives called interest rate derivatives. People's Bank of China issued the "The Notice of expanding the pilot of interest rate swap by People's Bank of China" at 9 February 2006, which also meant the forming of interest rate swap market in China. The trading volume, transaction types and participation organisations have developed rapidly since the interest rate swap market is formed. According to the statistics of Foreign Exchange Trading Centre, the nominal principals of interest rate swap increased from 218.7 billion yuan in 2007 to 4 trillion yuan in 2014. The transaction volume was 43,000. The main products benchmarked as Shibor O/N, FR007, Shibor 3M and 1yr Depo became the dominated products of interest rate swap according to the categories of transactions, specially FR007 and Shibor 3M. The transaction period mainly focused on below 5 years and exactly 5 years. In fact, the main participants included policy banks, four state-owned commercial banks, partial joint-stock banks, some insurance companies and some corporate customers related to deposit and loan in some commercial banks. Even though the regulations and policies allow corporate customers to hedge interest rate risk, the participation of domestic enterprises is still low. 
Table 2 the monthly report in recent 3 months in 2015 (FR007)

\begin{tabular}{|c|c|c|c|c|c|c|c|}
\hline $\begin{array}{c}\text { Reference } \\
\text { interest } \\
\text { rate }\end{array}$ & Period & \multicolumn{3}{|c|}{$\begin{array}{c}\text { Nominal principals (billion } \\
\text { yuan) }\end{array}$} & \multicolumn{2}{c|}{ Transaction volumes } \\
\hline \multirow{5}{*}{ FR007 } & & Jul & Aug & Sep & Jul & Aug & Sep \\
\cline { 2 - 9 } & 1 month & 2.600 & 0.020 & & 6 & 2 & \\
\cline { 2 - 9 } & 3 months & 203.800 & 192.750 & 125.100 & 409 & 358 & 263 \\
\cline { 2 - 9 } & 6 months & 102.050 & 109.525 & 124.100 & 220 & 269 & 356 \\
\cline { 2 - 9 } & 9 months & 26.379 & 77.248 & 105.220 & 119 & 307 & 415 \\
\cline { 2 - 9 } & 1 year & 237.939 & 386.899 & 175.180 & 2257 & 3505 & 1503 \\
\cline { 2 - 9 } & 2 years & 27.350 & 24.920 & 12.615 & 258 & 295 & 172 \\
\cline { 2 - 9 } & 3 years & 4.180 & 24.522 & 3.860 & 57 & 54 & 59 \\
\cline { 2 - 9 } & 5 years & 50.585 & 57.810 & 32.160 & 1555 & 1892 & 1126 \\
\hline
\end{tabular}

Sourcing: China Foreign Exchange Trade System (CFETS)

5-year treasury future is officially traded in $6^{\text {th }}$ September 2013. 10year treasury future is listed for transaction in $20^{\text {th }}$ March 2015, which will become an important reference for pricing long-term interest rates as a second product, promoting reformation of interest rates liberalization in China. Due to the weakness of current market economy, inflation and loose monetary policy, the weighted index of treasury future was up to $5.95 \%$ in 2014.

Since treasury future was listed for transaction, it shows good results on hedging, arbitrage and speculative trading. And hedging is suitable for the institutional investors. However, bank, insurance and so on, which have great demand, failed to participate treasury future market. And this leads to the size and volume are always between private investors and agencies, and securities and funds participation is relatively low. So it provides space and necessity to launch the bond forward.

Trading centre and Shanghai Clearing House provide a standard bond forward trading and centralized clearing service for market participation from $7^{\text {th }}$ April 2015, and issued standard bond forward contract and a series of rules. This is another important interest rate derivative after interest swap and treasury future.

Establishing an efficient financial market requires the liberalization of interest rates, which brings greater interest risk. Whether interest derivatives as risk hedging instruments can be effectively applied widely, depending on the degree of adaptability between benchmark interest rate and risk manager. In Chinese existing framework, low volume of short-term interbank money market leads to the difference between short-term benchmark and financing costs. And there is a deviation in long-term interest swap and lending rates 
because of existing framework. Now people's bank sets up benchmark lending rate with different maturities for corporations, and the correlation of benchmark lending rate and benchmark interest rate in money market is low. Corporate clients are difficult to use many interest swap tools to manage interest risk, so it leads to the correlation of long-term interest rate swap and financing cost declines. This phenomenon is reflected in the spread of different financial products on the market transactions. Over the past five years, the difference between highest and lowest spread of 5-year shibor interest rate swap and bond is 182 basis points. Compared to America, it is 43 basis points, and this data is only about $1 / 4$ of China.

At present, the tools can be used to manage interest risk are bond forward, treasury future, interest rate swap and so on in China, which are mainly for linear risk and do not have much power of defence for market volatility. With the advance of marketization of interest rate, market may fluctuate. The yield spread between highest and lowest of Chinese 10-year bond is 144 basis points in 2013, which is about 2.3 times of the previous three years. Thus, promoting more efficient and flexible risk management tools in domestic financial market is imminent. Range of market participants is also expanding and participants have accumulated sufficient experience on fundamental interest rate derivative instruments transaction. Since foreign exchange options market launched in 2011, market participants have full knowledge on characteristics and pricing methods on options. New transaction structures about derivatives continue to emerge in bond markets, and bond futures has some certain characteristics. Therefore, the timing of the introducing interest rate options has been basically mature.

\section{Transaction of Stock Derivatives}

Last year, the trading activities and position size of CSI300 futures have a certain degree of amplification, which largely benefited from the bull market in 2014. From the volume perspective, the annual volume of stock index future contract increased from 190 million in 2013 to 220 million in 2014. Meanwhile, the average daily volume of stock index future contract was 884000 in 2014, a lightly increase compared with 812000 in 2013. From the open interest perspective, the average daily open interest of stock index future contract was 164000 in 2014, which rose more than 50\% compared with 106000 in 2013. Along with the slight volume increase, the open interest experienced a sharp increase. It might largely due to that CFFEX (China Financial Future Exchange) further reduced the margin ratio of stock index future and adopted the unilateral deposit with calendar-spread arbitrage. Meanwhile, the stock market experienced a unilateral upward from 2014 Q4, and the open interest surged the new highs repeatedly. 
Although the value scale of Chinese stock market has been nearly 40 trillion $\mathrm{RMB}$, the problem of single product structure remains outstanding increasingly. As a mature fundamental financial derivatives tools in international market, stock options has important meanings in enriching the risk management tools, improving the market functions and promoting innovation. So 50ETF option was listed for transaction on the Shanghai Stock Exchange in $9^{\text {th }}$ February 2015 . This is the first option, which can be traded in Chinese capital market and open the prelude to development of option market.

\section{Transaction of Crediting Derivatives}

As the single risk structure of interest rate in bond market gradually adds credit risk, China developing mitigation tools to avoid credit risk becomes more and more important. From 1994, JP Morgan tried to make the CDS contract, which is the first tool to mitigate credit risk in international market. So the capacity of CDS in the world is very big. Compared to international market, the process of launching crediting derivatives is very slow in China. In early 2006, the National Development Bank and China Everbright bank made loan credit default swaps about 10 billion RMB. In October 2010, Interbank Dealers Association launched Chinese first interbank product to mitigate credit risk-CRM. It is an independent innovation product, including credit risk mitigation contracts, certificate, and others fundamental credit derivatives. For CRMA (Credit Risk Mitigation Agreement), there are 33 contracts with total face value of 260 billion Yuan by 2011, involving 13 bank counterparties. Although the process of crediting derivatives runs smoothly and orderly in China, it runs slowly. The main market participations are banking and financial institutions, and there are many problems as capital-release is not clear. So the future still requires much effort to promote.

\section{Conclusion and Developing}

The establishment and development of derivatives markets become the prominent features of financial market with the development of economy in China. Both of the stock exchange markets and the commodity future exchange market introduce the central counterparty mechanism, which also perform well in practicing. The need of developing China's OTC market becomes increasingly prominent with the deepening economical market reforms. The process of maturing and completing of OTC should be long because the China is still at the beginning. The gradual quitting in commodity derivatives could be based on the accumulated experience of monitoring and market trading in exchange rate and interest rate derivatives. In addition, the completing of monitoring system, matched laws and regulations, encouraging innovations and risk management should be designed by the feature of 
economic development and the condition of financial structure to form an impeccable transaction model in financial market.

\section{References:}

Han Chen, Financial Derivatives : Evolution Path and Supervision Measures, China Finance Press, 2008, ISBN: 9787504945723,7504945722 (In Chinese) Xiaochuan Zhou, Financial Policy Responses to Crisis, Journal of Financial research, 2011, ISCN: 1002-7246 (In Chinese)

Guang Huo, Characteristics and Regulation Research of Financial Derivatives, Chinese \& Foreign Entrepreneurs, 2013, ISSN: 1000-8772 (In Chinese)

Li Liu, Qing Yu, China Derivatives Market Analysis, Business Economy, 2013, ISSN: 1009-6043 (In Chinese)

China Financial Derivatives Annual Report, 2014 and 2015

China Commodities Data Report, 2015 